\title{
Gambaran Pengetahuan Penanganan Keputihan pada Remaja Putri di Salah Satu SLTP Jember
}

\author{
Veronika Vestine \\ Program Studi Rekam Medik, Jurusan Kesehatan, Politeknik Negeri Jember, \\ veronikavestine@polije.ac.id
}

\begin{abstract}
ABSTRAK
Remaja adalah suatu masa dimana individu menunjukkan tanda-tanda seksual sekunder sampai mencapai kematangan seksual, perubahan pada masa remaja terjadi dikarenakan adanya peningkatan kadar hormonal yang bisa menyebabkan keputihan. Keputihan dialami sekitar 50\% populasi wanita, dan 75\% wanita di Indonesia pernah mengalami keputihan paling tidak satu kali dalam hidupnya. Keputihan merupakan manifestasi gejala dari hampir semua penyakit kandungan,baik keputihan fisiologis maupun pathologis. Keputihan dapat ditangani dan dicegah dengan personal hygiene yang benar. Penelitian ini bertujuan untuk mendiskripsikan pengetahuan remaja putri tentang penanganan keputihan. Penelitian ini merupakan penelitian kuantitatif deskriptif dengan pendekatan cross sectional (Pada satu waktu yang bersamaan). Populasi penelitian ini adalah seluruh siswi remaja putri kelas VII dan VIII di salah satu SLTP. Sampel yang didapat berjumlah 74 siswi dengan teknik sampling total sampling. Hasil penelitian menunjukkan bahwa 52\% golongan remaja putri awal dan 55\% golongan remaja putri pertengahan memiliki pengetahuan cukup tentang penanganan keputihan, sedangkan 11\% golongan remaja putri awal dan 9\% golongan remaja putri pertengahan yang memiliki pengetahuan baik tentang penanganan keputihan. Sebanyak $45 \%$ responden mendapatkan informasi tentang keputihan berasal dari media televisi. Masih sedikitnya jumlah remaja putri yang memiliki tingkat pengetahuan yang baik tentang penanganan keputihan dapat diatasi dengan sosialisasi pemaparan pengetahuan tentang keputihan serta penanganan yang tepat untuk mencegah dan mengatasi keputihan.
\end{abstract}

Kata kunci: Pengetahuan, Remaja, Keputihan

\begin{abstract}
Adolescence is a period of individuals which shows the puberty changes until they reach the sexual maturity. While these changes occur due to an increase of hormonal levels, it causes the vaginal discharge in female adolescence. Vaginal discharge (leucorrhoea) affects about 50\% of female population and approximately 75\% of Indonesian women have experienced once in their life time. Both of physiological and pathological leucorrhea are a manifestation of uterine diseases symptoms. Leucorrhea can be treated and prevented by proper personal hygiene. The aim of this study is to describe the knowledge of female adolescence about leucorrhea management. The study was a descriptive quantitative with cross sectional approached. The samples were obtained from female students in junior high school grade VII and VIII. The 74 samples of female students were obtained by a total sampling technique. The 52\% of early female adolescence and 55\% of mid female adolescence have an adequate knowledge about leucorrhea management, whether 11\% of early female adolescence and $9 \%$ of mid female adolescence have a good knowledge about leucorrhea management. The 45\% respondents obtain the leucorrhea information from television. The lack information about leucorrhea or vaginal discharge can be solve by provide the good knowledge about prevention and administration itself.
\end{abstract}

Keywords: Knowledge, adolescence, leucorrhea.

*Korespondensi Author : Veronika Vestine, SST., M.Kes, Politeknik Negeri Jember, veronikavestine@polije.ac.id, Telp.082139063542

\section{PENDAHULUAN}

Pengetahuan merupakan hasil dari tahu, dan ini terjadi setelah orang melakukan penginderaan terhadap suatu objek tertentu. Penginderaan terjadi melalui panca indra manusia, yakni indra penglihat, pendengeran, penciuman, rasa dan raba. Sebagian besar pengetahuan manusia diperoleh melalui mata dan telinga. Pengetahuan atau kognitif merupakan domain yang sangat penting dalam membentuk tindakan seseorang (over behaviour). Dari pengalaman dan penelitian 
ternyata perilaku yang didasari oleh pengetahuan akan lebih langgeng dari pada perilaku yang tidak didasari oleh pengetahuan. ${ }^{1}$

Terdapat beberapa faktor yang mempengaruhi pengetahuan, yaitu faktor internal dan faktor eksternal. Faktor internal yaitu umur, pendidikan, dan pekerjaan. Faktor eksternal antar lain lingkungan, sosial budaya, dan pengalaman. ${ }^{1}$

Remaja merupakan masa peralihan antara masa anak dan masa dewasa yang berjalan antara umur 12 tahun sampai 21 tahun. Ada beberapa definisi tentang remaja salah satunya adalah Menurut psikologi, remaja adalah suatu periode transisi dari masa awal anak anak hingga masa awal dewasa, yang dimasuki pada usia kira kira 10 hingga 12 tahun dan berakhir pada usia 18 tahun hingga 22 tahun. Masa remaja bermula pada perubahan fisik yang cepat, pertambahan berat dan tinggi badan yang dramatis, perubahan bentuk tubuh, dan perkembangan karakteristik seksual. ${ }^{2}$

Keputihan adalah semua pengeluaran cairan alat genetalia yang bukan darah. Keputihan bukan penyakit tersendiri, tetapi merupakan manifestasi gejala dari hampir semua penyakit kandungan. Oleh karena itu, penyebab utama keputihan harus dicari dengan melakukan anamnesis (wawancara), pemeriksaan kandungan, dan pemeriksaan laboratorium. ${ }^{3}$

Keputihan adalah keluarnya cairan yang berlebihan dari vagina selain darah menstruasi. Keputihan ini merupakan keluhan yang umum terjadi pada wanita di dunia, terutama di wilayah Asia. World Health Organization (WHO) menyatakan bahwa 5\% remaja didunia terjangkit PMS dengan gejala keputihan setiap tahunnya, dan sebesar $75 \%$ wanita di seluruh dunia setidaknya mengalami candidiasis atau keputihan sebanyak satu kali dalam seumur hidupnya. ${ }^{4}$

Berdasarkan data Survei Kesehatan Reproduksi Remaja Indonesia (SKRRI) tahun 2010 menunjukan bahwa wanita yang rentan mengalami keputihan yaitu wanita yang berusia 15-24 tahun. Gejala keputihan yang dialami oleh remaja puteri, dalam 12 bulan terakhir menunjukkan remaja tersebut cukup banyak sebesar 31,8\%. Ini menunjukkan remaja putri mempunyai risiko lebih tinggi terhadap infeksi atau keputihan patologis. ${ }^{5}$

\section{METODOLOGI}

Penelitian ini bersifat deskriptif. Metode penelitian deskriptif adalah suatu metode penelitian yang dilakukan dengan tujuan utama untuk membuat gambaran atau deskriftif tentang suatu keadaan secara objektif. Penelitian ini menggunakan pendekatan cross sectional yaitu mengukur variabel dalam satu waktu yang bersamaan. ${ }^{6}$

Populasi pada penelitian adalah keseluruhan siswi remaja putri kelas VII dan VIII yang ada di salah satu SLTP di Kabupaten Jember sebanyak 74 siswi. Sampel yang digunakan berjumlah 74 siswi dengan teknik sampling menggunakan total sampling yaitu mengambil semua anggota populasi menjadi sampel. Teknik pengambilan data menggunaka kuesioner tentang tingkat pengetahuan penanganan keputihan.

Kriteria penilaian kuesioner tingkat pengetahuan menggunakan teknik prosentase. Tingkat pengetahuan Baik bila dapat menjawab pertanyaan dengan benar dengan prosentase 76100\%. Tingkat pengetahuan Cukup bila dapat menjawab pertanyaan dengan benar dengan prosentase $56-75 \%$. Tingkat pengetahuan Kurang bila dapat menjawab pertanyaan dengan benar dengan prosentase $<56 \%{ }^{7}$

\section{HASIL DAN PEMBAHASAN}

Kuesioner yang telah di isi oleh koresponden, lalu di tabulasi dan olah data dengan hasil sebagai berikut :

\section{Data Umum}

Tabel 1. Kelompok Umur Remaja Putri SLTP

\begin{tabular}{lcc}
\hline \multicolumn{1}{c}{ Kriteria } & Jumlah & $\begin{array}{c}\text { Presentas } \\
\mathrm{e}\end{array}$ \\
\hline $\begin{array}{l}10-14 \text { Tahun } \\
\text { (Remaja Awal) }\end{array}$ & 63 & $85 \%$ \\
$\begin{array}{l}15-16 \text { Tahun } \\
\text { (Remaja }\end{array}$ & 11 & $15 \%$ \\
\hline
\end{tabular}




\begin{tabular}{lll}
\hline Pertengahan) & \\
& & \\
\hline Total Pasien & 74 & $100 \%$ \\
\hline
\end{tabular}

Berdasarkan tabel.1 bahwa jumlah terbanyak responden berada di kelompok umur remaja awal (10 -14 tahun) yaitu 85\%. Untuk kelompok remaja pertengahan yaitu sebanyak $15 \%$.

Remaja merupakan masa peralihan antara masa anak dan masa dewasa yang berjalan antara umur 12 tahun sampai 21 tahun. Ada beberapa definisi tentang remaja salah satunya adalah Menurut psikologi, remaja adalah suatu periode transisi dari masa awal anak anak hingga masa awal dewasa, yang dimasuki pada usia kira kira 10 hingga 12 tahun dan berakhir pada usia 18 tahun hingga 22 tahun. Masa remaja bermula pada perubahan fisik yang cepat, pertambahan berat dan tinggi badan yang dramatis, perubahan bentuk tubuh, dan perkembangan karakteristik seksual. ${ }^{2}$

Seorang remaja pada tahap ini masih terheran-heran akan perubahan-perubahan yang terjadi pada tubuhnya sendiri dan dorongandorongan yang menyertai perubahan-perubahan itu. Mereka mengembangkan pikiran-pikiran baru, cepat tertarik pada lawan jenis, dan mudah terangsang secara erotis. Dengan dipegang bahunya saja oleh lawan jenis, ia sudah terfanrasi erotik. Kepekaan yang berlebihlebihan ini ditambah dengan berkurangnya kendali terhadap "ego" menyebabkan para remaja awal ini sulit mengerti dan dimengerti orang dewasa. ${ }^{8}$

Tabel.2 Sumber informasi yang didapat tentang keputihan

\begin{tabular}{lcccc}
\hline & \multicolumn{4}{c}{ Remaja } \\
\cline { 2 - 5 } Sumber & Remaja Awal & \multicolumn{2}{c}{$\begin{array}{c}\text { Remaja } \\
\text { Pertengahan } \\
\text { informasi }\end{array}$} & \multicolumn{3}{c}{$\begin{array}{c}\text { Presentas } \\
\text { Presentas }\end{array}$} & $\begin{array}{c}\text { Jumlah } \\
\text { e }\end{array}$ & Jumlah & e \\
\hline Televisi & 28 & $45 \%$ & 5 & $45 \%$ \\
Internet & 12 & $19 \%$ & 1 & $9 \%$
\end{tabular}

\begin{tabular}{lcccc} 
Radio & 11 & $17 \%$ & 2 & $18 \%$ \\
Buku & 12 & $19 \%$ & 3 & $28 \%$ \\
\hline Jumlah & 63 & $100 \%$ & 11 & $100 \%$ \\
\hline
\end{tabular}

Berdasarkan tabel.2 bahwa koresponden mendapatkan informasi tentang keputihan melalui televisi $(45 \%)$ ). Sebuah pengetahuan bisa didapat dan dipengaruhi oleh beberapa faktor, salah satunya faktor eksternal. Hasil penelitian menunjukkan bahwa koresponden mendapat informasi dalam hal ini pengetahuan tentang keputihan melalui perantara yakni media cetak dan media elektronik.

Sumber informasi juga dapat mempengaruhi tingkat pengetahuan seseorang, remaja putri yang mempunyai sumber informasi yang minim tentang keputihan menyebabkan mereka cenderung tidak mengerti tentang pentingnya pengetahuan yang berhubungan dengan keputihan. Hal ini terbukti dari hasil penelitian yang dilakukan ternyata masih ada yang mempunyai pengetahuan yang kurang tentang keputihan.

\section{Data Khusus}

Tabel 3. Tingkat Pengetahuan Remaja Putri tentang Penangan Keputihan

\begin{tabular}{ccccc}
\hline \multirow{2}{*}{$\begin{array}{c}\text { Tingkat } \\
\text { Pengetahuan }\end{array}$} & \multicolumn{2}{c}{ Remaja Awal } & \multicolumn{2}{c}{$\begin{array}{c}\text { Remaja } \\
\text { Pertengahan }\end{array}$} \\
\cline { 2 - 5 } & Jumlah & $\%$ & Jumlah & $\%$ \\
\hline Baik & 7 & $11 \%$ & 1 & $9 \%$ \\
Cukup & 33 & $52 \%$ & 7 & $55 \%$ \\
Kurang & 23 & $37 \%$ & 4 & $36 \%$ \\
\hline Jumlah & 63 & $100 \%$ & 11 & $100 \%$ \\
\hline
\end{tabular}

Berdasarkan tabel 3. bahwa mayoritas koresponden (52\% dan $55 \%$ ) memiliki tingkat pengetahuan yang cukup tentang penanganan keputihan. Hal ini masih belum cukup memuaskan, melihat psikologi remaja awal yang masih ingin serba tahu dan serba mencoba. Kejadian keputihan merupakan hal yang baru bagi mereka, bila tingkat pengetahuan mereka hanya dikisaran cukup, ditakutkan tidak bisa membedakan keputihan patologis dan fisologis, tidak dapat menentukan secara mandiri tindakan 
pencegahan dan penanganan bila terjadi keputihan. Kelompok tingkat pengetahuan baik hanya dimiliki oleh $11 \%$ remaja awal, dan $9 \%$ remaja pertengahan, yang merupakan kelompok minoritas.

$\begin{array}{cc} & \text { Menurut penelitian yang dilakukan oleh } \\ \text { Meliza menunjukan sebesar } \quad 69,7 \%\end{array}$ berpengetahuan baik, dan menyebutkan bahwa semakin dewasa umur seseorang, tingkat pengetahuan seseorang akan lebih matang atau lebih baik dalam berfikir dan bertindak. ${ }^{9}$ Hal ini juga sejalan dengan penelitian yang dilakukan oleh Ori Aprisia menunjukan sebesar 74,6\% pengetahuan baik tentang keputihan, bahwa pengetahuan seseorang terhadap suatu objek mempunyai intensitas atau tingkat yang berbeda-beda. sumber informasi, usia, pendidikan, sosial, ekonomi, dan budaya dapat mempengaruhi tingkat pengetahuan seseorang. ${ }^{10}$

Fluor albus terbagi atas dua macam yaitu fluor albus fisiologis (normal) dan fluor albus patologis (abnormal). Fluor albus fisiologis terdiri atas cairan yang kadangkadang berupa muskus yang mengandung banyak epitel dengan leokosit yang jarang, sedangkan fluor albus patologis banyak mengandung leokosit. Alat kelamin wanita dipengaruhi oleh berbagai hormon yang dihasilkan organ yakni: hipotalamus, hipofisis, ovarium dan adrenal. Estrogen dapat mengakibatkan maturasi epitel vagina, serviks, proliferasi stroma dan kelenjar. Sedangkan progesteron akan mengakibatkan fungsi sekresi. Keputihan normal dapat terjadi pada masa menjelang dan sesudah menstruasi, sekitar fase sekresi antara hari ke 10-16 siklus menstruasi, saat terangsang, hamil, kelelahan, setres dan sedang mengkonsumsi obat-obat hormonal seperti pil KB. Keputihan ini tidak berwarna atau jernih, tidak berbau dan tidak menyebabkan rasa gatal. ${ }^{11}$

Berdasarkan penelitian secara epidemiologi, keputihan patologis dapat menyerang wanita mulai dari usia muda, usia reproduksi sehat maupun usia tua dan tidak mengenal tingkat pendidikan, ekonomi, dan sosial budaya, meskipun kasus ini lebih banyak dijumpai pada wanita dengan tingkat pendidikan dan sosial ekonomi yang rendah. ${ }^{12}$

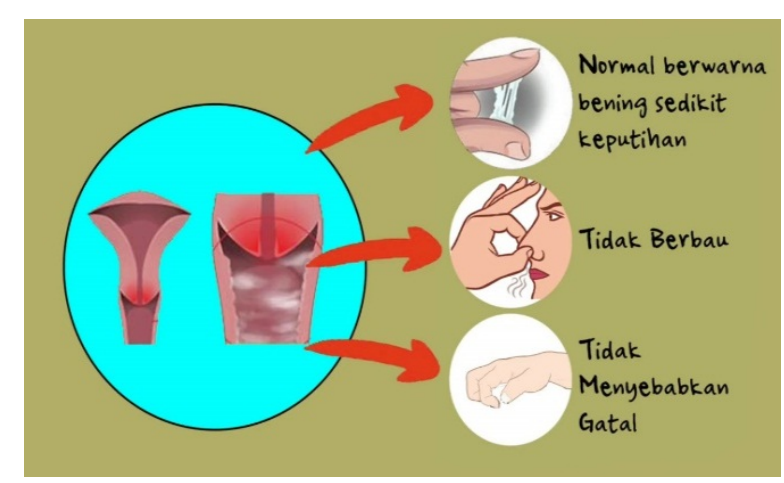

Gambar 1. Kondisi cervix vagina dalam kondisi normal

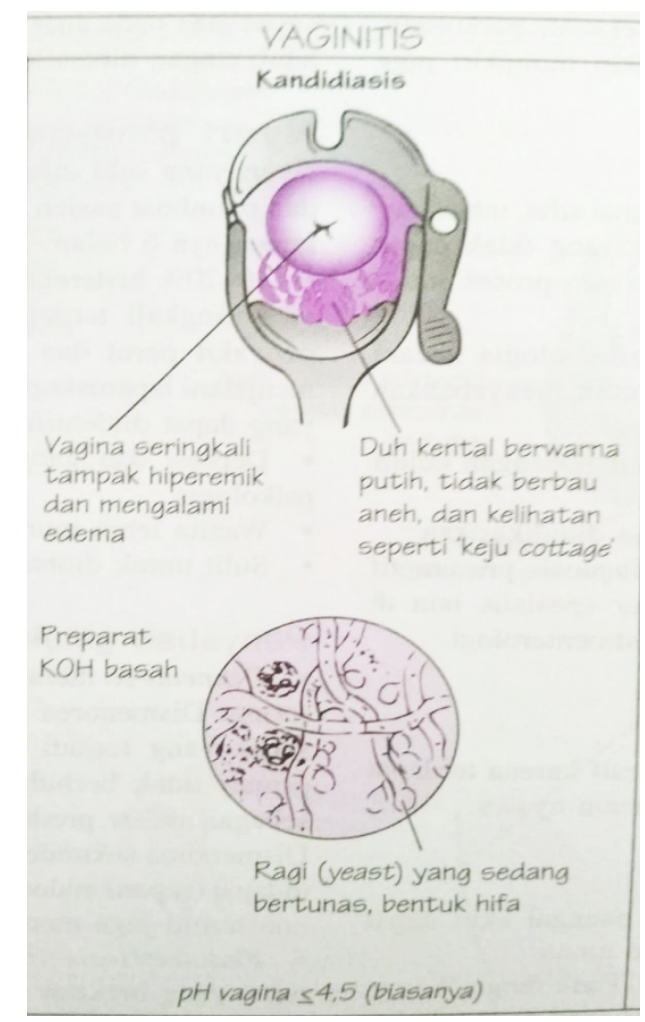

Gambar 2. Kondisi Vagina dalam kondisi Kandidiasis $^{13}$ 


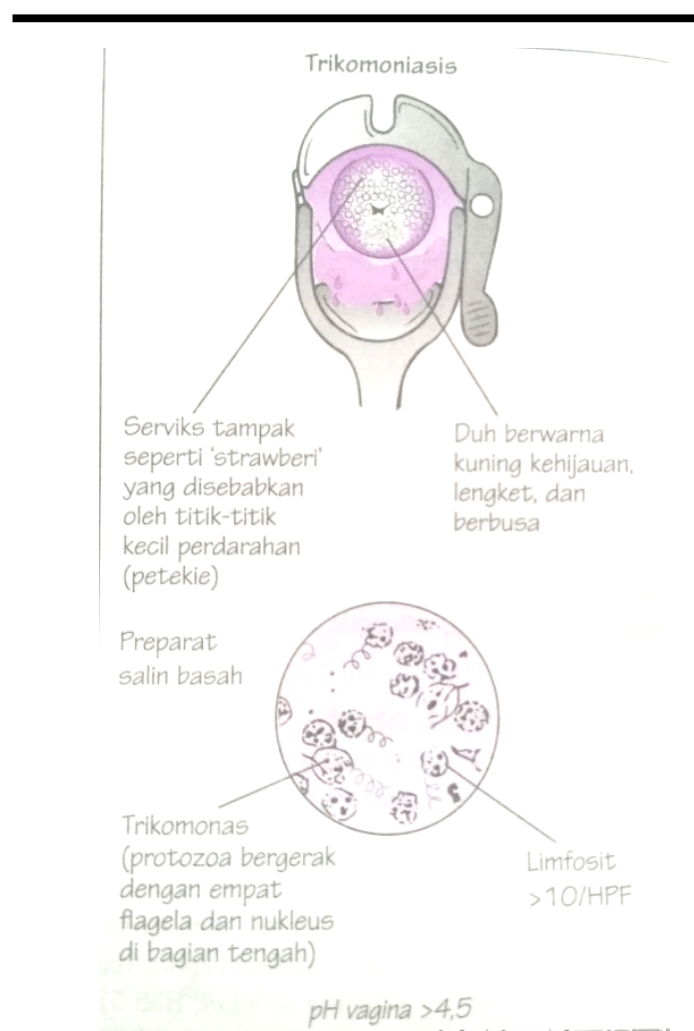

Gambar 3. Kondisi Vagina dalam kondisi Trikomoniasis $^{13}$
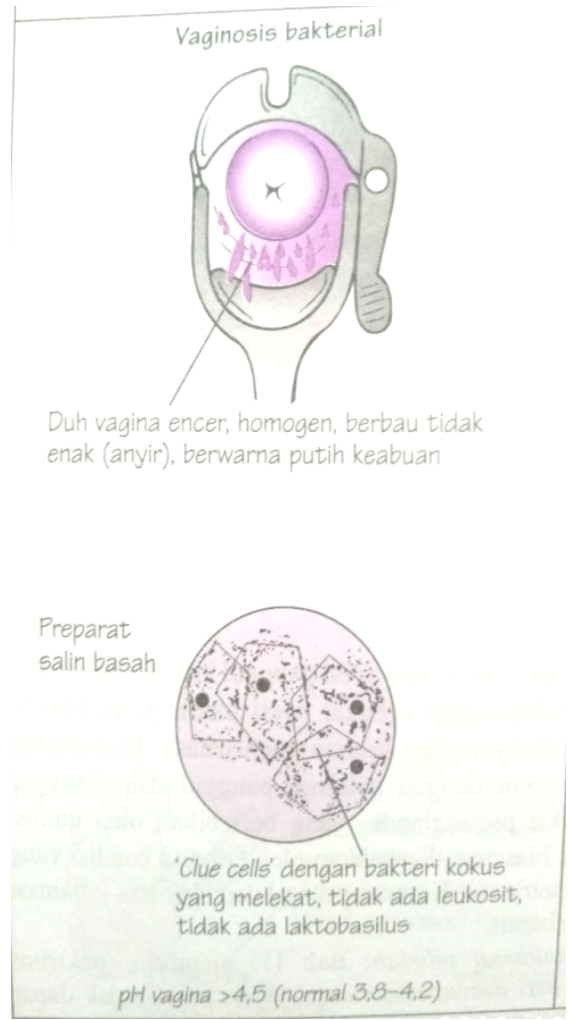

Gambar 4. Kondisi Vagina dalam kondisi Vaginosis Bakterial ${ }^{13}$

Berdasarkan penelitian oleh Nikmah (2018), keputihan patologis disebabkan oleh minimnya personal hygiene habits. Kesalahan cara membersihkan organ kewanitaan, penggunaan handuk bersama, frekuensi penggunaan pembalut dan pantyliner yang belum tepat, frekuensi pemotongan bulu kemaluan yang jarang, penggunaan pakaian dalam yang lembab dan jarang diganti, penggunaan antiseptik khusus organ kewanitaan yang kurang tepat, dan penggunaan air yang kurang higienis dengan keadaan lingkungan yang kotor. Kebiasaan dalam membersihkan diri yang tidak tepat dapat menyebabkan rentan terinfeksi oleh bakteri, virus, maupun jamur. Hal ini disebabkan personal hygiene habits merupakan salah satu pertahanan diri seseorang agar terhindar dari penyakit-penyakit yang mudah menginfeksi. ${ }^{14}$

Keputihan yang fisiologis dapat berubah menjadi patologis, namun hal tersebut dapat dicegah dengan personal hygiene yang benar. Salah satu cara pencegahan terjadinya keputihan yaitu : ${ }^{15}$

\section{Jaga kebersihan vagina}

Menjaga kebersihan vagina merupakan hal yang paling penting untuk mencegah keputihan akibat infeksi berbagai bakteri. Membersihkan vagina dengan sabun mandi akan mengganggu keseimbangan $\mathrm{pH}$. Kadar $\mathrm{pH}$ normal pada vagina adalah sekitar 3,8 - 4,5, sedangkan sabun mandi biasa cenderung memiliki $\mathrm{pH}$ sekitar 7 - 8. Setiap wanita memiliki tingkat sensitif yang berbeda pada vaginanya, ada wanita yang tidak memiliki masalah jika memakai sabun mandi biasa untuk membersihkan vagina, namun ada yang mengalami iritasi dan alergi jika memakai sabun biasa.

Sebuah hal yang normal jika vagina memiliki aroma, karena aroma pada vagina dapat berubah-ubah sesuai dengan siklus reproduksi yang terjadi, sehingga tidak bias diktetapkan bahwa vagina yang mengeluarkan bau dianggap terjadi infeksi. Disaat siklus menstruasi berlangsung, vagina lebih sering dibersihkan dan diganti pembalut sesering 
mungkin, hal ini bertujuan menjaga kebersihan dan kelembapan vagina. Seka vagina dengan tisu bersih, dari bagian depan ke belakang (arah vagina ke anus). Hal ini untuk menghindari bakteri yang ada di sekitar anus berpindah ke vagina.

2. Ganti pakaian dalam

Mengganti pakaian dalam setidaknya 2 hingga 3 kali dalam sehari dapat membantu menjaga kebersihan vagina. Dengan cara ini, menghindarkan bakteri 'tinggal' di vagina dan juga dapat menurunkan aroma yang tidak sedap pada vagina. Pemakaian bahan pakaian dalam yang salah dapat menjadi salah satu faktor risiko vagina terkena infeksi bakteri. Pakaian dalam yang berbahan katun memudahkan vagina untuk 'bernapas'. Kurangi pemakaian celana ketat seperti jeans yang dapat membuat vagina mudah mengalami iritasi.

3. Melakukan hubungan seksual yang aman

Banyak penyakit seksual yang diakibatkan oleh bakteri yang tertular ketika melakukan hubungan seksual, seperti klamidia, gonore, herpes genital, sifilis, dan HIV. Penyakit-penyakit menular seksual dapat dikenali dengan gejala keputihan yang patologis.

4. Pemeriksaan serviks rutin

Wanita yang berusia 25-64 tahun dianjurkan untuk melakukan pemeriksaan serviks secara rutin. Pemeriksaan ini bertujuan untuk mendeteksi apakah terdapat perubahan abnormal pada leher rahim dan jika ada dapat dideteksi dari awal. Hal ini juga dapat mendeteksi kanker leher rahim pada wanita. Keputihan patologis juga merupakan gejala yang menyertai kondisi abnormal di sekitar leher rahim.

5. Mengonsumsi makanan yang sehat

Makanan sangat berpengaruh pada kesehatan, termasuk kesehatan vagina. Mengonsumsi makanan yang sehat dan cairan yang cukup, dapat menjaga kesehatan reproduksi Anda sekaligus mencegah keputihan yang tidak normal.

\section{SIMPULAN DAN SARAN}

Mayoritas tingkat pengetahuan remaja putri di salah satu SLTP di Kabupaten Jember tentang penangan keputihan adalah cukup, yakni $52 \%$ pada kelompok remaja awal dan $55 \%$ pada kelompok remaja pertengahan. Tingkat pengetahuan baik hanya dimiliki oleh $11 \%$ kelompok remaja awal dan $9 \%$ kelompok remaja pertengahan, yang merupakan sekelompok kecil remaja.

Diharapkan kepada remaja putri untuk meningkatkan pengetahuan tentang penangangan keputihan baik melalui media cetak, elektronik, maupun berkonsultasi langsung dengan petugas kesehatan. Beberapa cara penanganan yang bisa dilakukan yaitu dengan menjaga kebersihan vagina, mengganti pakaian dalam, melakukan hubungan seksual yang aman, pemeriksaan serviks rutin, dan mengkonsumsi makanan yang sehat. Bagi petugas kesehatan, diharapkan untuk memberikan edukasi dan sosialisasi secara langsung pada kelompok remaja, agar mereka mendapatkan informasi secara langsung face to face.

\section{UCAPAN TERIMA KASIH}

Ucapan terima kasih kami sampaikan kepada :

1. Dinas Pendidikan Kabupaten Jember yang telah memberi ijin untuk melaksanakan penelitian di salah satu SLTP dalam naungan wilayah kerjanya.

2. Kepala sekolah, guru, serta koresponden yang telah bersedia meluangkan waktu dan tenaga selama penelitian berlangsung.

3. Redaksi Jurnal ARTERI yang bersedia menerbitkan artikel ini dalam edisi terbitnya.

4. Serta pihak-pihak yang tidak bisa kami sebut satu persatu.

\section{REFERENSI}

1. Soekidjo, Notoatmodjo. Ilmu Perilaku Kesehatan. Jakarta : Rineka Cipta; 2010.

2. Eureka Pendidikan. Indonesia : Pendidikan; 2015 (updated 2015 February 03; cited 2019 Ocktober 


20). Available from :

http://www.eurekapendidikan.com/

3. Manuaba, Ida Ayu C, Dkk. Ilmu kebidanan, Penyakit Kandungan \& Kb Untuk Pendidikan Bidan. Jakarta: Buku Kedokteran EGC; 2010

4. Widyasari, Dian Tri. Faktor-Faktor yang berhubungan dengan Perilaku Pencegahan dan Penanganan Keputihan Patologis pada Mahasiswi Kebidanan STIK Bina Husada Palembang tahun 2014. Palembang: STIK Bina Husada

5. BPS (Badan Pusat Statistik), dan ORC MACRO. Survey Kesehatan Reproduksi Remaja Indonesia. Calveston, Maryland, USA : BPS dan ORC Macro. 2010

6. Notoatmodjo, Soekidjo. Metodologi Penelitian Kesehatan. Jakarta : Rineka Cipta; 2012

7. Arikunto. Prosedur Penelitian Suatu Pendekatan Praktik. Jakarta : Rineka Cipta; 2010

8. Sarwono, Sarlito Wirawan. Psikologi Remaja. Jakarta : PT.Raja Grafindo Persada; 2012.

9. Amelia, Meliza., Yulia, Irvani., Darwin. Gambaran Perilaku Remaja Putri Menjaga Kebersihan Organ Genetalia dalam Mencegah Keputihan. 2012. FIK-UNRI.

10. Putri, Ori P. Gambaran Tingkat Pengetahuan dan Sikap Remaja Putri terhadap Keputihan di SMA Negeri 2 Pontianak. 2014. FK Universitas Tanjungpura.

11. Sibagariang, dkk. Kesehatan Reproduksi Wanita. Jakarta : Trans Info Medika; 2010.

12. Ramayanti. Pola mikroorganisme fluor albus patologis yang disebabkan oleh infeksi tahun $2004 \quad$ (tesis). Semarang FKUNDIP/RSKARIADI.2004

13. Errol Norwitz \& John Schorge. At a Glance Obstetri Dan Ginekologi. Jakarta : Erlangga; 2008.

14. Umi Sa'adatun Nikmah, Hesty Widyasih. Personal Hygiene Habits dan Kejadian Fluor Albus Patologis pada Santriwati PP ALMunawwir, Yogyakarta. JURNAL MKMI. 2018; Vol. 14 No. 1.

http://journal.unhas.ac.id/index.php/mkmi/article /view/3714

15. Hello Sehat. Jakarta : Informasi Kesehatan; 2017 (Updated Juni 19 2019, cited November 24 2019) available from http://hellosehat.com/hidup-sehat/perawatankewanitaan/cara-mengatasi-menghilangkankeputihan/ 